\title{
Groundwater dependent ecosystems. Part I: Hydroecological status and trends
}

\author{
Bjørn Kløve ${ }^{a, b, *}$, Pertti Ala-aho ${ }^{a}$, Guillaume Bertrand ${ }^{c}$, Zuzana Boukalova ${ }^{d}$, \\ Ali Ertürk ${ }^{e}$, Nico Goldscheider ${ }^{f}$, Jari Ilmonen ${ }^{a}$, Nusret Karakaya ${ }^{g}$, Hans Kupfersberger ${ }^{h}$, \\ Jens Kvœrner ${ }^{b}$, Angela Lundberg ${ }^{i}$, Marta Mileusnić ${ }^{j}$, Agnieszka Moszczynska ${ }^{k}$, \\ Timo Muotka ${ }^{a}$, Elena Preda ${ }^{l}$, Pekka Rossi ${ }^{a}$, Dmytro Siergieiev ${ }^{i}$, Josef Šimek ${ }^{d}$, \\ Przemysław Wachniew ${ }^{m}$, Vadineanu Angheluta ${ }^{l}$, Anders Widerlund ${ }^{i}$ \\ ${ }^{a}$ Water Resources and Environmental Engineering Laboratory, Department of Process and Environmental Engineering, \\ University of Oulu, PO Box 4300, FIN-90014, Finland \\ ${ }^{\mathrm{b}}$ Bioforsk - Norwegian Institute for Agricultural and Environmental Research, Soil and Environment Division, \\ Frederik A. Dahls vei 20, N-1432 Ås, Norway \\ c University of Neuchâtel, Rue Emile-Argand 11 - CP 158, CH - 2009 Neuchâtel, Switzerland \\ ${ }^{\mathrm{d}}$ GIS-Geoindustry s.r.o., Jindricha Plachty 16, 15000 Praha 5, Czech Republic \\ e Istanbul Technical University, 34469 Maslak, Istanbul, Turkey \\ ${ }_{\mathrm{f}}^{\mathrm{f}}$ Karlsruhe Institute of Technology (KIT), Institute for Applied Geosciences, Department of Hydrogeology, \\ Kaiserstr. 12, D-76131 Karlsruhe, Germany \\ ${ }^{g}$ Abant Izzet Baysal University, 14280 Bolu, Turkey \\ ${ }^{\mathrm{h}}$ Joanneum Research Forschungsgesellschaft mbH Elisabethsr. 16/II, A - 8010 Graz, Austria \\ ${ }^{\mathrm{i}}$ Luleå University of Technology, SE-971 87 Luleå, Sweden \\ ${ }^{\mathrm{j}}$ University of Zagreb; Pierottijeva 6, HR-10000 Zagreb, Croatia \\ ${ }^{\mathrm{k}}$ Universita Cattolica del SacroCuore, Via Emilia Parmense 84, 29100 Piacenza, Italy \\ ${ }^{1}$ University of Bucharest - Splaiul Independentei 91-95, 050095 Bucharest, Romania \\ ${ }^{\mathrm{m}}$ AGH University of Science and Technology, Mickiewicza, 30 30-059 Krakow, Poland
}

\section{A R T I C L E I N F O}

\section{Article history:}

Received 6 January 2011

Received in revised form

2 April 2011

Accepted 4 April 2011

Published on line 23 May 2011

Keywords:

Hydrology

Ecology

Vulnerability

\begin{abstract}
A B S T R A C T
Groundwater dependent ecosystems (GDEs) include valuable ecosystems such as springs, wetlands, rivers, lakes and lagoons. The protection of these systems and services they provide is highlighted by international agreements, i.e. Ramsar convention on wetlands, and regional legislation, i.e. the European Water Framework Directive. Groundwater provides water, nutrients and a relatively stable temperature. However, the role of groundwater in surface ecosystems is not fully understood. The ecosystem can depend on groundwater directly or indirectly, and the reliance can be continuous, seasonal or occasional. This has implications for the vulnerability of ecosystems, as some may be easily affected by external pressure. Conceptual models and quantitative assessments of how groundwater interacts with the environment are needed. GDEs are also threatened by different land use activities and climate change. Hence, we need to understand how GDEs are affected by changes in
\end{abstract}

\footnotetext{
* Corresponding author at: Water Resources and Environmental Engineering Laboratory, Department of Process and Environmental Engineering, University of Oulu, PO Box 4300, FIN-90014, Finland. Tel.: +358 40 5944514; fax: +358 85534507.

E-mail addresses: bjorn.klove@oulu.fi (B. Kløve), guillaume.bertrand@unine.ch (G. Bertrand), zboukalova@gmail.com (Z. Boukalova), erturkal@gmail.com (A. Ertürk), goldscheider@kit.edu (N.Goldscheider), karakaya_n@ibu.edu.tr(N.Karakaya), hans.kupfersberger@joanneum. at (H. Kupfersberger), jens.kvarner@bioforsk.no (J. Kvœrner), angela.lundberg@ltu.se (A. Lundberg), marta.mileusnic@rgn.hr (M. Mileusnić), agnieszka.moszczynska@unicatt.it (A. Moszczynska), elena.preda10@gmail.com (E. Preda), wachniew@agh.edu.pl (P.Wachniew). 1462-9011/\$ - see front matter (C) 2011 Elsevier Ltd. All rights reserved.

doi:10.1016/j.envsci.2011.04.002
} 
Climate change

Land use

Groundwater groundwater quantity and quality, as severe groundwater changes have been observed in many regions. This study examines key aspects of GDEs (hydrogeology, geochemistry and biodiversity) in order to improve conceptual understanding of the role of groundwater in such ecosystems. The status and baseline of different types of GDEs are discussed, with particular emphasis on past evidence of environmental change and potential thresholds and threats in GDEs in various parts of Europe with different land use, climate and geology.

(C) 2011 Elsevier Ltd. All rights reserved.

\section{Introduction}

GDEs may be defined as ecosystems for which current composition, structure and function are reliant on a supply of groundwater. GDEs are a vital but as yet not fully understood component of the natural environment. In many cases groundwater makes an important but poorly documented contribution to various aquatic and terrestrial ecosystems such as: (I) rivers and lakes including aquatic, hyporheic, and riparian habitats, (II) subterranean aquifers and caves, (III) wetlands and springs, and (IV) estuarine and nearshore marine ecosystems (adapted from Boulton, 2005). The aquifer itself is also an important ecosystem (Danielopol and Pospisil, 2001).

The ecosystem reliance on groundwater may be continuous, seasonal or occasional, e.g. a few months every few years. The reliance becomes apparent when the supply of groundwater is removed for a sufficient length of time that changes in plant function (typically rates of water use decline first) can be observed. Groundwater is often the main source of water for vegetation in dry climates. Some systems, such as springs, are completely fed by groundwater and would not otherwise exist. This is also reflected in fauna and flora, with springs harbouring many species adapted to these special conditions. In general, groundwater provides water, nutrients, buoyancy, and stable water temperature, but the effects of this on GDEs are not thoroughly documented.

GDEs and associated aquatic ecosystems are important to protect as they provide many ecosystem services. A few GDEs, such as some wetlands, are important as habitats for migratory birds or rare plant and invertebrate species, and are protected by international and local agreements and legislation. Wetlands have been protected by the international Ramsar convention on wetlands since 1971. In Europe, legal actions with strong commitments for environmental protection include the Habitat Directive (EC, 1992) with the Natura 2000 network of protected sites and a strict system for species protection.

In Europe, groundwater is threatened by land-use, pollution and extensive water use for irrigation. The Water Framework Directive (EC, 2000) aims to achieve good quality of surface and ground water by 2015 . Therefore, groundwater threshold values must be set to protect associated aquatic ecosystems and human health (Hinsby et al., 2008). Protection of surface waters is also needed from an economical and recreational point of view. The Groundwater Directive (EC, 2006) lists several pollutants that should be monitored and provides regulations to limit pollution, reverse upward trends in pollutant concentration in groundwater, and protect groundwater resources. It requires that nearby ecosystems relying on groundwater must not be damaged by changes in chemical, hydrological or ecological status. For assessment of vulnerability of these ecosystems, more information is needed on the role of groundwater in ecosystems (Hinsby et al., 2008).

This paper examines the role of groundwater in different ecosystems and highlights the hydrogeological and ecological properties of GDEs. The status, trends and future risks of some GDEs are reviewed to provide examples of the impact of past land use and climate, a key objective being to identify the overall impacts of land use and climate change on GDEs. These impacts are often interwoven and therefore complex to understand. Present knowledge and conceptual models on how GDEs are linked to groundwater are used to clarify the chain of events leading to changes in GDEs after changes in land use and climate and serve as a starting point or baseline for future management and protection. The basis of such models is information on hydrogeology and its role in geochemistry and biodiversity. Such information is provided in this paper, which to our knowledge represents the first rigorous attempt to link these different scientific disciplines in a more complete understanding of GDEs. A better understanding of the interaction between groundwater and surface water ecosystems is needed for future policy, including how to set groundwater threshold values for the Water Framework Directive (Hinsby et al., 2008). This paper focuses on ecosystems with a large portion of groundwater but also includes the role of groundwater in several systems not yet classified as GDEs. This is done to highlight the potential role and importance of groundwater. Detailed information on assessment of large lakes and costal waters where groundwater input is limited can be obtained elsewhere (e.g. Borja, 2005; Camargo and Alonso, 2006; Hinsby et al., 2008). Different aspects of ecosystem services, protection and management are covered in an accompanying paper (Kløve et al., this issue)

\section{Hydrogeological and biological processes in groundwater and in groundwater dependent ecosystems}

\subsection{Hydrogeology}

Groundwater moves along flow paths from recharge areas to discharge areas within GDEs (Fig. 1). Recharge occurs everywhere when meteroric water (including retarded fractions such as snow and glaciers) enters the ground. Water then usually moves through the unsaturated zone and reaches the saturated part of the aquifer. Some surface waters both receive and recharge groundwater. Groundwater recharge may 


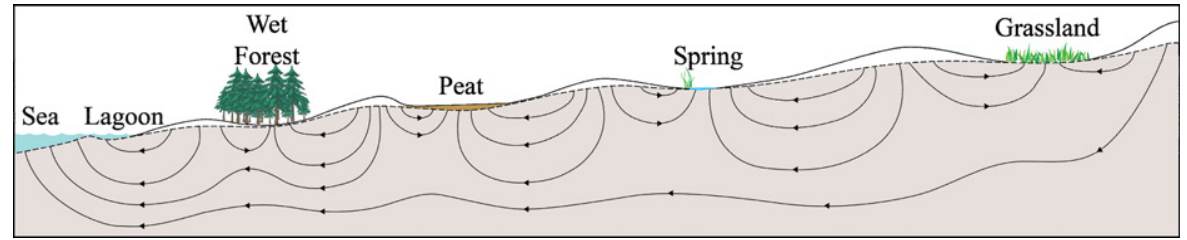

Fig. 1 - Flow lines and groundwater levels in a cross-section of soil/rock with homogeneous and isotropic hydraulic conductivity, with possible locations of GDEs.

include contribution from adjacent aquifers. Discharge from the aquifer occurs at springs, streams, lakes and wetlands, as transpiration by plants with roots that extend to near the watertable, and by direct soil evaporation. Groundwater can also discharge to adjacent aquifers (e.g. downward leakage from an aquifer to a deeper one). Groundwater typically discharges to surface water bodies where the slope of the water table changes suddenly (e.g. Winter et al., 1998). In many cases springs are found where geological layer and hydraulic conductivity change.

The actual conceptual model for a given aquifer will vary locally depending on water use, slope, topography, climate and geology. This should also include the unsaturated zone which plays a very important role both for groundwater quantitative and qualitative aspects. Local groundwater flow is often near the surface and occurs over short distances, i.e. from a higher elevation recharge area to an adjacent discharge area such as small springs. Intermediate and regional flows usually occur at a greater depth and over greater distance. Steeper and undulating landscapes have the most local flow points. Groundwater flow is always threedimensional, but can often be analysed in two-dimensional sections (Fig. 1). Analysis of these flow paths is important when studying GDEs because it can provide valuable information about potential threats to both the quantity and quality of groundwater.

Different ecosystems depend on groundwater in complex ways. Some springs, such as karstic systems, show very high variations of discharge or often run dry occasionally (intermittent springs). Peatlands fed by surface flow, rain and groundwater are adapted to stable watertables fluctuating near the soil surface. Fens receive a continuous supply of groundwater and bogs receive only precipitation on the surface but groundwater pressure provides buoyancy and prevents drainage. The hydrogeology and multi-scale flow patterns influence both the timing and duration of groundwater discharge (hydroperiod). From a hydroecological point of view, the concept of hydroperiod provides an interesting starting point for the classification of GDEs because it integrates several abiotic parameters (drivers), e.g. climate, extent of flow paths, aquifer type (i.e. porous or discontinuous) and land use of the catchment, which eventually constrain ecological uses of groundwater. Four types of hydroperiods can be distinguished (adapted from Alfaro and Wallace, 1994):

- Periodic: usually a clear seasonal pattern, average discharge climatically controlled (precipitation/evapotranspiration changes).

- Intermittent: great variability in flow.
- Episodic: completely irregular flow, occurring only when there are very high water levels in the aquifer.

- Perennial: continuous source year round.

As a function of these features, the importance of groundwater supply relative to other potential water sources varies. A constant supply of groundwater normally maintains dependent ecosystems such as wetlands and springs typically located in landscape depressions. Here, groundwater is most likely the sole source of water. The high contribution of groundwater compared with other water sources can be seen if (i) the water quality directly reflects that of groundwater, or in dry climates (ii) if the transpirative water losses from vegetation are maintained by groundwater. As these systems exhibit a rather constant temperature that differs from that of adjacent surface waters, temperature can also be used as a tracer to evaluate the degree of groundwater-surface water interaction (Anibas et al., 2011). In addition, GDEs can include plants that indicate weathering products from groundwater.

A spatially and temporally integrated view of relations between the GDEs and the local and regional groundwater flow systems can be provided by environmental tracers such as stable isotopes of water, tritium, noble gases, CFCs or $\mathrm{SF}_{6}$ (e.g. Kværner and Kløve, 2006) Besides their significance in developing conceptual and numerical models of flow and transport in groundwater systems the environmental tracers allow identification and quantification of sources of discharge to GDEs as well as dating of groundwater. Knowledge of groundwater age distribution is a key factor in the assessment of GDE vulnerability to climate and land-use changes, groundwater exploitation and pollution. Dominant time scales of water flow and solute transport to the ecosystem determine time lags associated with its responses to both commencement and cessation of such disturbances.

\subsection{Geochemistry}

Geology and water residence time are the two fundamental factors controlling natural water chemistry. Groundwater provides nutrients and electron acceptors (e.g. sulphate), and usually creates specific physico-chemical conditions in GDEs. Water $\mathrm{pH}$ determines the solubility and biological availability of nutrients and of heavy metals. At lower $\mathrm{pH}$, metals tend to occur in bioavailable forms, while different nutrients are best taken up at $\mathrm{pH}$ levels offering suitable adsorption conditions. Redox potential is an important parameter in reductive dissolution of iron oxyhydroxides and the state of redox-sensitive elements. In GDEs linked to surface waters, seasonal and daily variations in photosynthesis can be a major natural cause of $\mathrm{pH}$ variations. 
Therefore, modification of water chemical balance may result in irreversible changes in the entire GDE.

A wide range of physical, chemical and biological processes controls subsurface mass transfer between the solids, gases and fluids in groundwater aquifers. Many reactions in natural waters involve interactions between acids and bases. Chemical weathering reactions consume hydrogen ions from $\mathrm{H}_{2} \mathrm{CO}_{3}$ and organic acids, thus increasing $\mathrm{pH}$ and determining the $\mathrm{C}$ speciation in the carbonate system (Winter et al., 1998). Precipitation reactions are responsible for mineral formation from dissolved constituents present in water, potentially transferring large quantities of matter between dissolved and solid phases. Discharging groundwater carries dissolved mineral constituents that, depending on $\mathrm{pH}$ and redox conditions, may precipitate in internal boundaries of GDEs (Stumm, 1992).

Biodegradation involves oxidation of organic matter into simple inorganic compounds, usually in microbially catalysed processes. Oxygen is the major electron acceptor in oxidised surface systems, while in anoxic groundwater aquifers $\mathrm{NO}_{3}{ }^{-}$, $\mathrm{Fe}^{3+}, \mathrm{Mn}^{4+}, \mathrm{SO}_{4}{ }^{2-}$ and $\mathrm{CO}_{2}$ act as electron acceptors. Redox reactions influence the mobility of metal ions in solution. Under anoxic, sulphidic conditions, both metal ions and sulphur are removed from the solution as solid metal sulphides. Once sulphides are exposed to oxygen, sulphide-bound metals may be released in bioavailable forms. Exposition of peat sulphides to oxygen due to groundwater lowering in dry periods can lead to oxidation of sulphides to sulphate and result in acidification of stream water (Devito and Hill, 1997).

\subsection{Biodiversity}

Biodiversity is the total variety of life, including genetic, population, species and ecosystem diversity. This includes the relationships between different biotic compartments and their ecological roles under specific physico-chemical conditions and hydrogeomorphological units. Thus, even if seasonal variations in water temperature and discharge regime are small, groundwater carries a continuous flux of dissolved ions, nutrients and organic matter essential for species inhabiting GDEs. These particular ecosystems make an important contribution to the regional biodiversity of freshwater and wetland ecosystems, linking groundwater and surface water, as well as groundwater and terrestrial ecosystems (Boulton, 2005; Barquin and Scarsbrook, 2008).

In subterranean systems, lack of light limits the functional diversity of producers and grazers but dissolved organic matter and biofilm typically support a complex food web dominated by detritivores (Boulton, 2005). An extraordinary endemic biodiversity and large proportions of relict species including highly specialised microorganisms and micro-, meio- and macrofauna, the stygobionts, have been found in these systems. Nearly 7000 stygobiont invertebrate taxa have been recorded in groundwater, mostly comprising of crustaceans, about 2000 of which occur in Europe. Subterranean groundwater is a habitat of low accessibility, and dispersal between separate aquifers, and even within an aquifer, is extremely limited. Factors driving the local diversity of stygobionts remain largely unknown, but the permeability of aquifers and their proximity to surface water systems, influencing habitat connectivity and species pool availabili- ty, are among the most important known factors (Gibert et al., 2009).

Springs, the smallest and most distinct type of aboveground GDE, are often regarded as structurally and functionally simple habitats. However, springs include lentic (spring pool), lotic (spring brooks), and semi-terrestrial (helocrene, marshy seepage area) habitats, often forming habitat complexes of high heterogeneity (Barquin and Scarsbrook, 2008). Springs are inhabited by (i) surface water species, (ii) species more dependent on groundwater, and (iii) terrestrial or wetland species that benefit from the buffering capacity of groundwater against drought and extreme temperatures. Emergent mosses provide a particularly diverse environment that changes horizontally from the edges to the inner parts of the moss carpet, and vertically from dry to submersed habitats through a madicolous transition zone. The moss carpet thus provides an ecotone between terrestrial and aquatic conditions, and it is known as a habitat of high invertebrate diversity. Moss is a preferred habitat for many crenobiont (obligate spring species) arthropods.

The chemical composition of the emerging groundwater, mainly the acidic-calcareous gradient reflecting aquifer soil and bedrock composition, is perhaps the single most important factor influencing plant community composition and species richness in springs. This gradient even overrides such generally important factors as light availability and latitudinal gradient (Virtanen et al., 2009). Plant species richness peaks at intermediate levels of $\mathrm{pH}$ and electrical conductivity, while extremely acidic or calcium-rich spring-fed wetlands are generally species-poor (Poulíčková et al., 2006).

The special environmental conditions (e.g. high environmental stability) of GDEs favour the occurrence of highly specialised and regionally restricted species (Gibert et al., 2009), thus increasing their value for overall biodiversity. Local species richness, and especially the occurrence of endemics, appears to depend on the geological history of a locality, especially the Pleistocene glaciations. For example, in Europe the ratio of endemic to total species richness of stygobionts decreases towards the north (Gibert et al., 2009), where the Last Glacial Maximum was more extensive. A corresponding pattern can be seen in the distribution and abundance of certain springdependent species, e.g. the crenobiont caddis fly Crunoecia irrorata (Curtis), which is more common and abundant in southern than northern Europe, where glaciation history and/or climate restricts its distribution (Ilmonen, 2008). Furthermore, spring specialists are more common in southern than northern Europe, and springs of the most recently glaciated areas are dominated by insects instead of crustaceans, owing mainly to the higher dispersal ability of insects. However, glacial cycles do not wipe regions completely clean of all life, as species can survive in subsurface groundwater, further stressing the importance of groundwater to regional biodiversity.

On moving from the subterranean groundwater and springs to larger GDEs with less dependence on groundwater, the habitat becomes more complex, sustaining higher biodiversity. Springs, for example, with their specialist flora and fauna, are a vital component of riverine landscape biodiversity, especially in headwater reaches (Ward and Tockner, 2001).

In arid areas, springs provide mesic refugia for plants and animals. Wetland plant species cannot survive in arid zones 
without access to groundwater, a good example being riparian and wetland species growing in desert environments. A key aspect of groundwater-vegetation interactions in general is the mechanism of water uptake by plants. Root function plays a central role in the ecohydrological dynamics of humid land ecosystems, and in complex feedbacks between abiotic and biotic factors. Watertable dynamics affect the vertical distribution of roots, as the frequency and duration of flooding determine root growth strategies and allocation of plant resources (Laio et al., 2009).

Flow stability is a key driver of macroinvertebrate diversity in streams. GDEs, although generally more stable than surface water bodies and wetlands, also exhibit somewhat variable flow permanence, depending on their water source type (see Section 2.1). Stability of groundwater input is clearly a key determinant of GDE biodiversity. For example, permanent springs support more species of mayflies, stoneflies and caddis flies than do intermittent springs (Smith et al., 2003). However, Barquin and Death (2004) found lower macroinvertebrate species richness in springs compared with runoff-fed streams. The reduced diversity in springs could be a result of a
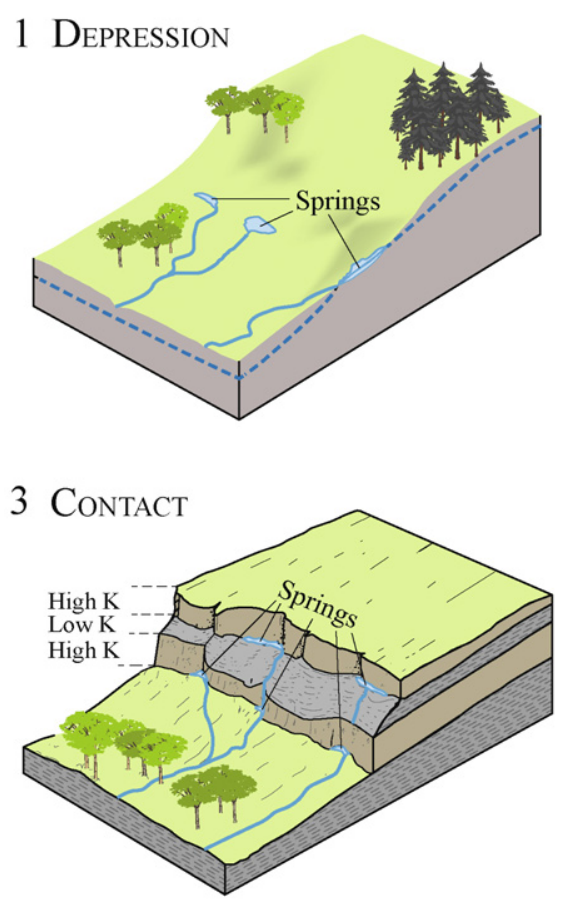

5 SinKHOLE

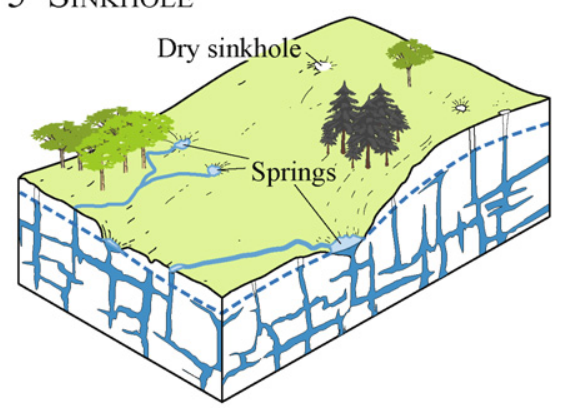

higher predation risk or the unusually constant thermal characteristics of spring habitats.

An analysis of biodiversity in GDEs in Oregon showed that of the nearly 1650 species of conservation concern, 9\% were obligately (141 species) and 31\% facultatively groundwater dependent (511 species) (Brown et al., 2009). The taxonomic groups in which groundwater dependence was most important were aquatic molluscs. Of insect species, $76 \%$ of the dragonfly/stonefly/mayfly group and $42 \%$ of caddis flies present were obligately groundwater dependent. In addition, 9\% of non-vascular plants, including 25 liverworts, were obligately groundwater dependent (Brown et al., 2009).

\section{Status and trends of groundwater dependent ecosystems}

\subsection{Springs}

Springs are typically found in groundwater discharge zones in areas with large differences in hydraulic conductivity (Fig. 2B

\section{FAULt}

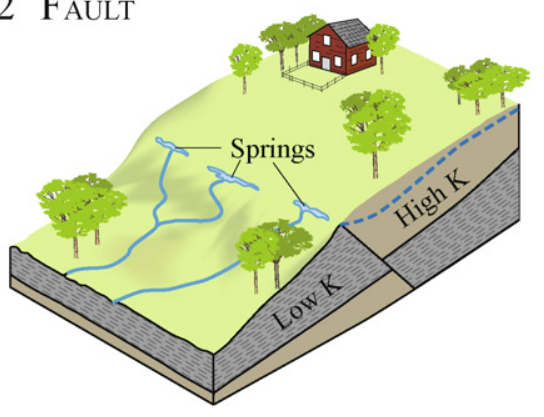

4 FRACTURE

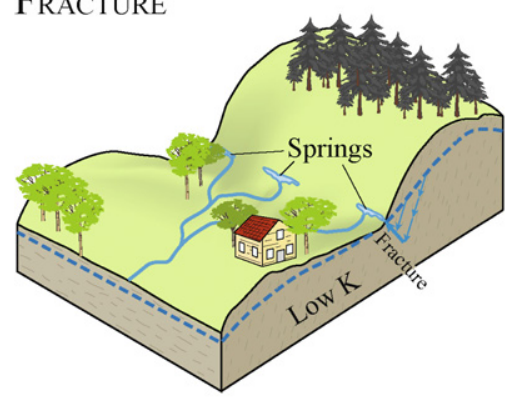

6 Fracture zone

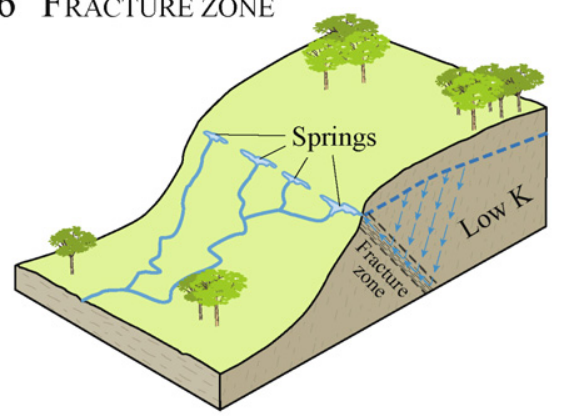

Fig. 2 - Different types of springs. In many cases springs are found where the geological layer and hydraulic conductivity change (modified after Fetter, 2001). 
and C) or in fractured rocks (Fig. 2D-F). Only depression springs are found in homogeneous soil/rock. Springs are a very distinct type of GDE and typically receive only groundwater. Springs can also be located next to streams and lake shores, with potential inundation and surface water mixing during high flow periods. Depending on the aquifer type, climate and catchment size, spring flow ranges from $<0.1 \mathrm{~L} / \mathrm{s}$ to more than $100 \mathrm{~m}^{3} / \mathrm{s}$.

Karst springs are fed by water flowing in the conduit network of the aquifer, which results from the dissolution of carbonate rocks (Alfaro and Wallace, 1994). Karst spring discharge is often highly variable between baseflow and high flow periods, with a quick response to storm rainfall or snow and glacier melt (Gremaud and Goldscheider, 2010). Most of the largest springs are karst springs. The variability of spring flow is commonly associated with marked changes in water quality. Biocenoses in karst spring GDEs need to adapt to this variability. Šraj-Kržič et al. (2007) demonstrated that the nonpermanent water regime of some alpine karst springs leads to an amphibious-dominant macrophyte community, which has higher regeneration and dispersal abilities compared with purely aquatic species. Crenon studies also show that sites with buffered discharge include macroinvertebrate taxa of relatively low mobility and long generation times. In contrast, sites with highly variable discharge are dominated by species with high mobility and multivoltinism (Barquin and Scarsbrook, 2008).

The rapid transport of contaminants in the conduits results in a high vulnerability of karst springs to human impacts (Ravbar and Goldscheider, 2007). Storage and slow release of groundwater from the rock matrix and deep zones of the aquifer supplies baseflow to springs and is crucial in predicting possible climate change impacts on the associated GDEs. Although karst springs are the most obvious and frequent type of karst GDE, they are not the only GDEs associated with karst (Bonacci et al., 2009). Intermittent karst lakes and lakes formed by sinter terraces are other relevant types (see below). Finally, the karst aquifer itself should be considered an ecosystem, as high biodiversities of crustaceans and even vertebrates, such as fish and amphibians, can be found in karst aquifers (Humphreys, 2006).

Fontanili (Fig. 3) are semi-natural springs found in the Po river flood plains of Italy. Historically these plains were covered with a mosaic of wetlands, streams and small lakes (Minelli et al., 2002), but vertical pipe drainage was introduced in the 11th century to increase arable land area. A typical fontanili consists of a head, which resembles a small circular pond where the water flows out to the surface facilitated by the installed tube; a 'throat', a bottleneck that connects the head with the body of the fontanili; and a excavated channel that enables further water flow into neighbouring streams.

While the temperature in most aquatic environments in the Po River plain varies between slightly above 0 and $30^{\circ} \mathrm{C}$ (Laini et al., 2010), the mean water temperature in the fontanili oscillates between 10 and $16{ }^{\circ} \mathrm{C}$. Fontanili waters reach their highest temperatures in autumn and their lowest during early spring (De Luca et al., 2005). Water fluxes in the fontanili are quite constant throughout the year, $\mathrm{pH}$ is usually neutral, and oxygen levels in the fontanili head do not reach saturation levels. The groundwater that supplies the system was

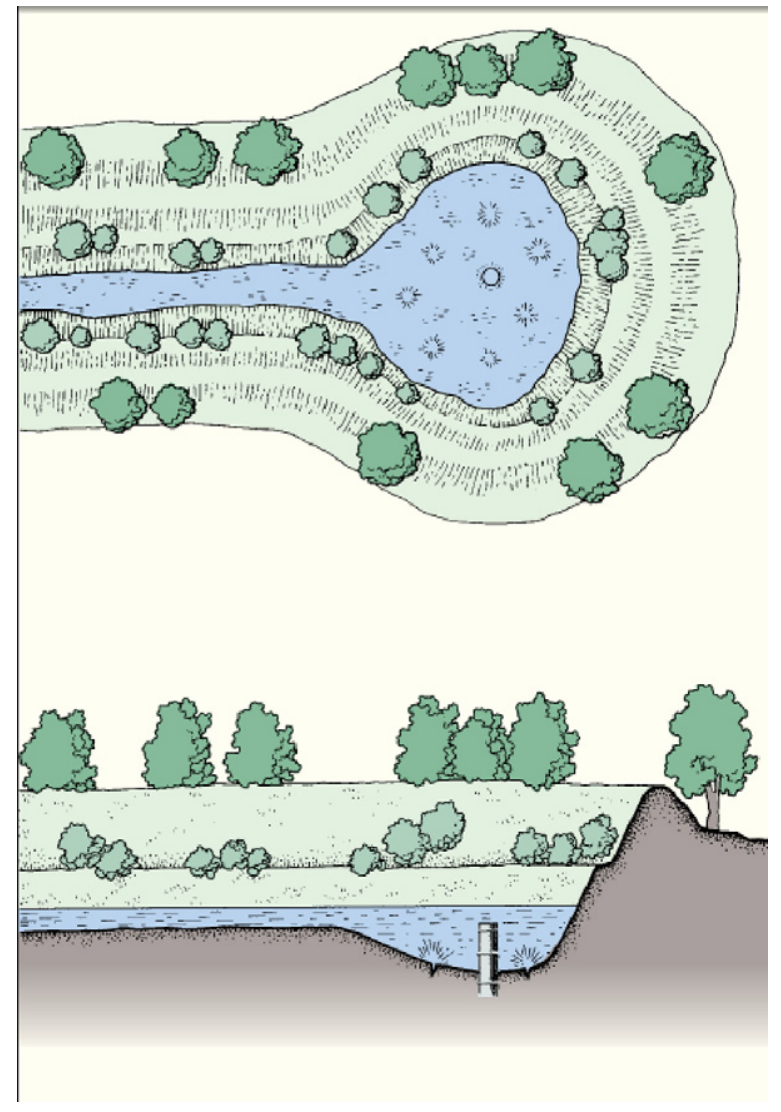

Fig. 3 - Morphology of a typical fontanili (Minelli et al., 2002). The diameter is normally $0.9-4.0 \mathrm{~m}$, but can be up to $150 \mathrm{~m}$.

originally poor in nutrients. However, the groundwater in the area is now reported to have elevated nitrate levels (up to $150 \mathrm{mg} \mathrm{N}-\mathrm{NO}_{3}{ }^{-} / \mathrm{L}$ ), which is an effect of diffuse agricultural contamination.

The Po Valley represents the biggest agricultural area in Italy, with $75 \%$ of the land being cropped annually. The main problem related to the fontanili water quality is contamination with pesticides and nutrients. A relatively effective way to lower the risk of contamination in these water bodies is by maintaining riparian buffer strips. Unfortunately, the fontanili are rarely properly protected from contamination, as crops are often grown too close to the fontanili banks. Another problem is that many fontanili are disappearing due to excessive groundwater pumping. Waste filling and the complete burial of fontanili create additional risks.

\subsection{Rivers and the hyporheic zone}

Most streams gain water as they travel from their headwaters towards lakes and seas, although some streams lose water through either permeable river beds or high evaporation. Groundwater exfiltration occurs when the groundwater level at the stream edges is above the stream water level, and infiltration occurs when the stream water level exceeds the groundwater pressure head (Fig. 4). Exfiltration and infiltration are influenced by water extraction (e.g. irrigation), land use (e.g. mining) and hydropower regulation. For example in Spain 

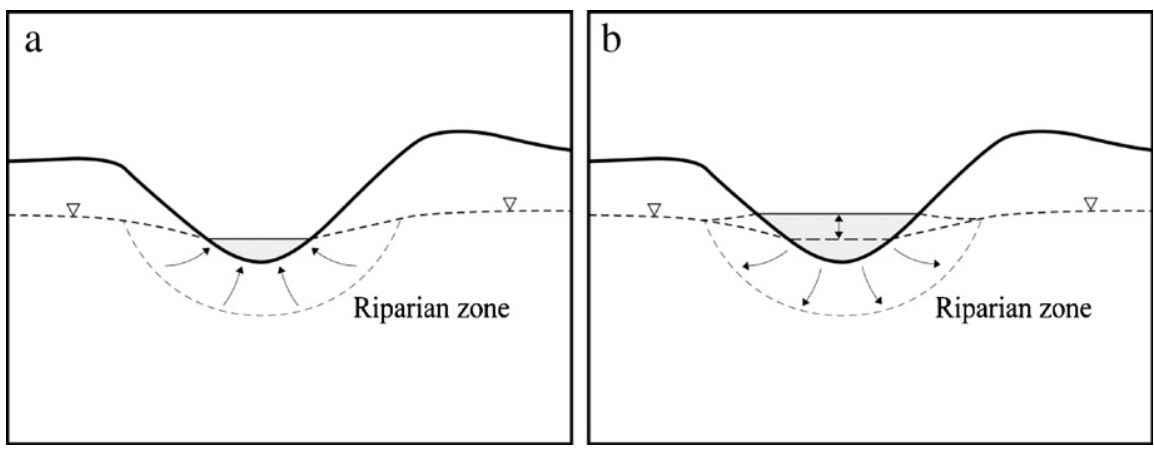

Fig. 4 - River stages, groundwater levels and flow paths during (a) exfiltration and (b) infiltration of river water to bank storage.

and Greece irrigation has reduced flow to rivers and GDE (Kløve et al., this issue) with considerable impact on ecological status, especially during the summer low flows (Menció and Mas-Pla, 2010).

In the context of reducing emissions of greenhouse gases, exploitation of hydropower is a central component of the energy master plan in many European countries. Although the impacts of river regulation on river waters are fairly well documented (e.g. Humborg et al., 2006), the impacts on groundwater systems are less well known (Sawyer et al., 2009).

In pristine northern rivers, the groundwater levels and river stages are normally synchronised, so high water stages coincide with high groundwater levels and rivers gain (Fig. 4a), even if shorter stretches of the river might be losing. However, in regulated rivers high water stages are likely to occur even when the groundwater levels are low and the river will lose water to surrounding aquifers (Fig. 4b) and vice versa. When short-term regulation is applied the river may change from gaining to losing and back again within a day, resulting in a disturbed and eroded hyporheic zone with reduced filtering capacity. River stages have been shown to be important in controlling the water quality in the hyporheic zone of a regulated river (Arntzen et al., 2006). In basins or valleys with sand and gravel deposits in central Europe, sheet piles are often added to river dams to minimise water seepage losses and to prevent seepage failure of the dam. However, these sheet piles disconnect the groundwater from the surface water and thus have significant consequences for the groundwater system.

An example of a river-groundwater system influenced by hydropower construction is the Sava river with Zagreb aquifer system $\left(350 \mathrm{~km}^{2}\right.$, single source of potable water for the capital of the Republic of Croatia). Along the Sava river course, there are several valuable and important protected freshwater and bird habitats. River regulation and construction of a hydroelectric dam in the upstream reaches have resulted in enhanced erosion, and a deepening of the river bed to 5-6 $\mathrm{m}$ has occurred in the last 40 years. This has resulted in a decline in groundwater levels and desiccation of connected swamp habitats.

\subsection{Lakes}

The role of groundwater in lake ecology is not known in detail. It is likely that the conditions depend on the hydrogeology, climate and -trophy (nutrient status). Shallow lakes are typically abundant in a young geological landscape such as the area covered by the last glaciation. In these areas groundwater typically discharges in seepage zones or subwater springs into either fully mixed (spring and autumn) or seasonally stratified (dimictic) lakes. During winter, oxygen depletion is a problem in shallow lakes rich in organic matter. Groundwater can maintain ice-free hot-spots or breathing holes along shorelines where oxygen can enter from the air. Although groundwater is often depleted in oxygen by subsoil geochemical reactions, it sometimes provides oxygen for lakes. In deeper lakes, formed by e.g. tectonic action, groundwater has an important impact on deep water quality. Groundwater can also influence processes in the sediment.

Lakes are relatively rare in karst areas, but there is a great variety of lake-groundwater interactions. Two types of karst lakes require specific mention, as they represent unique and valuable GDEs: intermittent karst lakes and lakes formed by sinter terraces. Intermittent karst groundwater lakes can be found in Ireland, where they are referred to as 'turloughs', but also in Slovenia and probably in several other regions (Skeffington and Scott, 2008). These lakes are connected to karst conduits. They often fill and empty via the same conduit, or they fill via intermittent springs and empty via swallow holes. Watertable fluctuations can exceed $10 \mathrm{~m}$ and there are

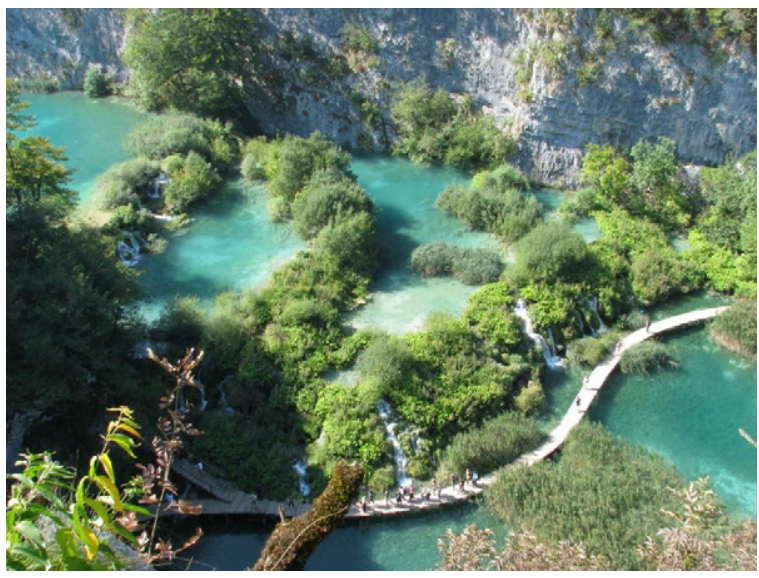

Fig. 5 - Image of the Plitvice GDE lakes fed by karst springs, where the precipitation of calcium carbonate from water has created terraces that act as natural dams for the lakes. (Photo: N. Goldscheider). 
unique GDEs associated with these lakes, including plant and animal species that are adapted to extreme hydrological changes (Porst and Irvine, 2009).

The type of karst lakes that form upstream of sinter terraces act as natural dams and the sinter terraces can convert the typical morphology of streams into a series of terraced pools. An extreme example is the Plitvice Lakes in Croatia (Fig. 5), a UNESCO world natural heritage site. The sinter terraces here were formed, and are still forming, by the precipitation of calcium carbonate from karst water. This water mostly originates from karst springs upstream of the lakes, discharging groundwater from a complex regional karst aquifer system.

\subsection{Wetlands and peatlands}

Peatlands form a large proportion of the land area in the boreal zone, where the landscape typically consists of peatlands, springs, lakes and esker aquifers that are sometimes connected hydraulically. Peatlands are rich in biodiversity and have many ecosystem functions. In Finland, peatlands are included in most of the over 1800 designated Natura 2000 sites, many of which were chosen to protect the most valuable remaining wetland and peatland ecosystems. In the boreal zone in Finland, the most intensive drainage took place in the 1950s-1970s to increase forest growth. Since the 1970s, about 60000 ha of Finnish peatlands have also been drained for peat harvesting, mainly for energy or as garden soil. Along with peatland drainage, an extensive network of forest roads has been constructed since the 1950s. A typical example of the negative impacts of roads can be seen in the Clara bog in Ireland. In general, the impacts of drainage are complex and derive from many land use activities, such as road construction, forestry and agriculture. In Finland, anthropogenic impacts on springs are mainly caused by forest and peatland drainage. The degree of anthropogenic disturbance in springs varies regionally, being very extensive in the southern part of the country ( $>90 \%$ of springs disturbed) and negligible in the north, where most springs are pristine. In central Europe, peatland management started with early agriculture about a thousand years ago and, due to improved drainage practices, it was intensified during the latter part of the 19th century.

Damage to peatlands has been noted after tunnel construction in Norway (Kvœrner and Snilsberg, 2008), due to leaking of groundwater and lake and peat water to the tunnel through fracture zones in crystalline rocks (Fig. 6). In normal conditions, the watertable and flow velocity in wetlands located in a depression depend on the local water balance or surplus of water. In a stable situation the regional flow has little or no impact on the variation in the water balance components of the wetland. However if hydrological modifications occur, then these may become apparent in the regional flow patterns. A reduction in regional flow will then increase the flow from the wetland to the deeper groundwater and result in a decrease in the water level and dryer conditions. This was seen in Norway, where peat surfaces were compacted and degraded after drainage for tunnel construction (Kvœrner and Snilsberg, 2008). Similar impacts have been reported in southern Europe. For example, a largescale tunnel project in Tuscany, Italy, has caused severe environmental damage. Nine high-speed railway tunnels with a total length of $73 \mathrm{~km}$ were drilled across the Northern Apennine, through marl, sandstone and limestone formations. The tunnels were built as drainage tunnels and caused regional lowering of the groundwater level by up to $100 \mathrm{~m}$ and total alteration of the natural groundwater flow systems. As a consequence, more than 10 mountain streams and 30 springs have been affected and the associated GDEs are heavily damaged (Vincenzi et al., 2009).

Forest ditches in peatlands in groundwater esker discharge areas pose a threat that is often overlooked. Peatlands are typically located adjacent to the esker, where they confine the flow. After the peatland is drained, the groundwater below the peat layer can discharge into the ditches with less resistance. Groundwater can either discharge through the peat layer through distinct 'erosion pipe channels' (Fig. 7 section a) or, if the ditch is cut through the peat, groundwater can seep through the mineral soil channel bed in a diffuse manner (Fig. 7section b). In Northern Finland (Rokua esker), variations in groundwater level have been noted since the 1980s. The reasons for these variations are related to forestry, natural climate variability and climate change. The variations have also affected water levels in groundwater dependent oligotrophic kettle lakes situated on the esker (Fig. 7). Lower lying lakes are eutrophic, with a constant water level, probably due to deeper groundwater inflow and constant outflow from the lakes.

\subsection{Wet forests}

Wet forests above aquifers can depend on groundwater. An example is the Niepołomice lowland forest covering around $110 \mathrm{~km}^{2}$ between the river Vistula and its tributary Raba to the east of Krakow (Poland) (Fig. 8). The area includes protected Natura 2000 habitats for birds and butterflies. The Niepołomice Forest also contains several nature reserves and the European bison breeding centre and has an important recreational value as the largest forest complex in the vicinity of Krakow. The topography and surface geology of the area were shaped during

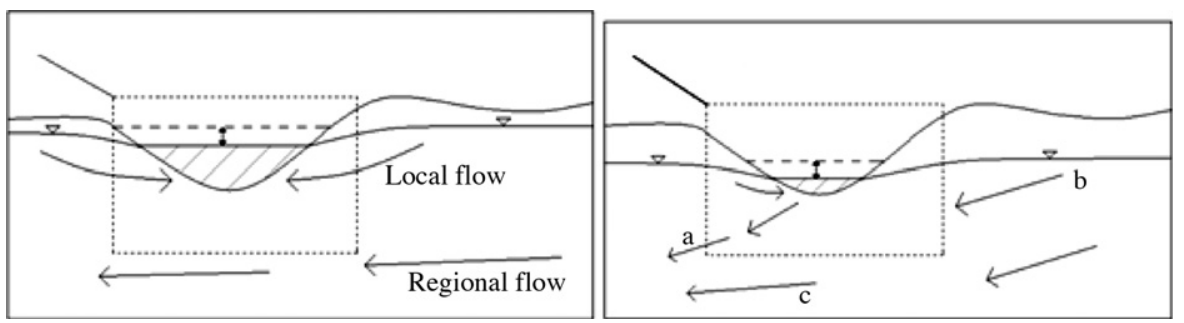

Fig. 6 - Conceptual presentation of flow paths in a GDE before and after lowering of the groundwater level. 

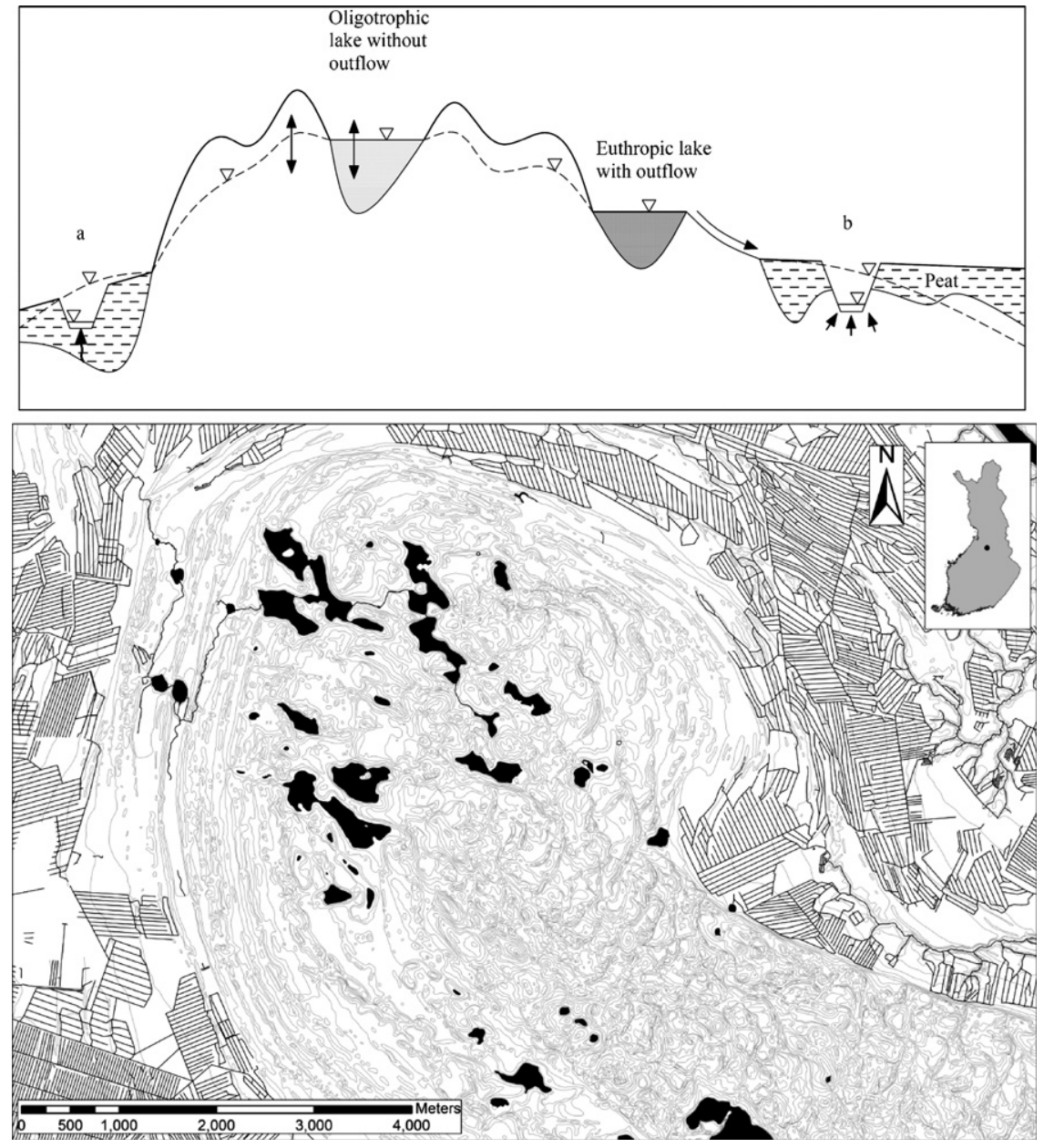

Fig. 7 - Esker groundwater and dependent lake levels and effect of confining peatland ditches on esker groundwater (a) with point pipe discharge or (b) with seepage discharge through ditch mineral beds (the horizontal scale is greatly exaggerated). The size of these lakes is usually $0.1-1 \mathrm{~km}$, with the esker width varying from $100 \mathrm{~m}$ to $5 \mathrm{~km}$ and length from $1 \mathrm{~km}$ to $80 \mathrm{~km}$. The eskers typically form chains in the direction of the glacial retreat. Several eskers are joined over a distance of $300-1000 \mathrm{~km}$.

the Quaternary period, mainly by fluvial and fluvioglacial processes. Tertiary sands and sandstones comprise an important groundwater basin, the Bogucice, confined by clays and claystones. The dependency of the Niepołomice Forest on groundwater is enhanced by low available water capacity and low capillary rise of the soils at the site. Groundwater conditions may have been affected by former drainage activities and forest management (Lipka et al., 2006). Groundwater levels in the Niepołomice Forest may be also affected by exploitation of the

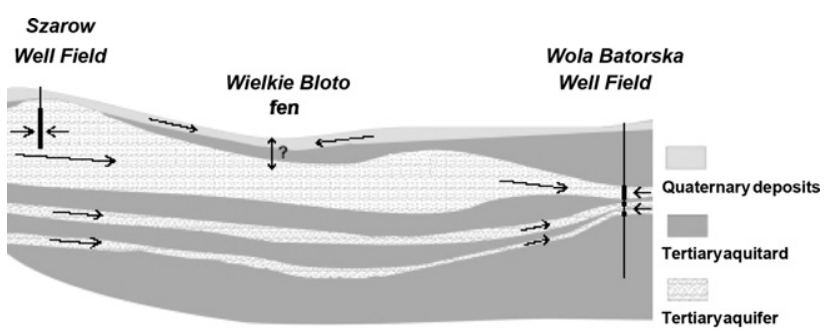

Fig. 8 - Schematic diagram of the Bogucice aquifer and the Niepołomice Forest and fen. tertiary aquifer, although the extent of hydrological connection between that aquifer and the shallow groundwater in the Quaternary deposits is unknown.

\subsection{Coastal lagoons}

Coastal lagoons are shallow water bodies separated from the ocean by a barrier, connected at least intermittently to the ocean by one or more restricted inlets, and usually orientated parallel to the shore. Lagoons provide a collection of habitat types, including salt marshes, sea grasses and mangroves, for many species. Most of these coastal ecosystems are very dynamic and productive (Gönenç and Wolflin, 2005) and they are usually used for fisheries and aquaculture exploitation. Coastal lagoons form an integral part of marine fisheries and provide important spawning and nursery grounds for many fish species. Coastal lagoons may also control the nutrient fluxes into the marine environment.

Due to spatial salinity differences, many habitats can form within small distances. Therefore, the ratio of fresh and saline water inflows is crucial for the ecology of coastal lagoons. Thus, 
one of the possibly serious threats is the decrease or loss of surface and groundwater inputs and/or increase of seawater inflow. In addition to the salinity gradient, freshwater also affects primary and secondary production, water quality, mixing, stratification, residence time and geomorphological structure in coastal lagoons. Therefore, a decrease in freshwater inputs to a coastal lagoon may be harmful to its ecosystem and may even destroy habitats within or near the lagoon.

\section{Discussion and conclusions}

Groundwater provides an important contribution to unique terrestrial and aquatic ecosystems such as springs and wetlands. These systems are typically of high value as they support high biodiversity and provide the habitat for several endangered species. Some of these ecosystems and related water bodies have been protected to a certain extent by international conventions such as the Ramsar convention and, in Europe, by several laws such as the Habitat and Water Framework Directive. For protection, more information is needed on their functioning to assess their status and impacts of land and water use, pollution and climate change. Such basic information includes integrated multidisciplinary knowledge on hydrology, geochemistry and biology from individual systems as well as on the scale of regional catchments and aquifers.

GDEs comprise a large variety of ecosystems that are found in different hydrogeological, climatic and geographical settings from headwaters to coastal lagoons. Groundwater flow paths differ between the systems; some receive recent water whereas others are fed by water with a long transit time or even sea water. This influences the geochemistry and temperature variation in the systems. Baseflow periods are often characterised by higher major ion concentrations and alkalinity, stable temperatures and low turbidity, due to the long water-rock interaction and filtration in the matrix. Fairly stable conditions can persist at all times in some springs characterised by only long transit times. In these systems, the discharge is expected to increase only with changes in the regional groundwater flow caused by climate variation or land use changes. However, some GDE show high discharge variability, which can also affect water quality.

Due to differences between GDEs, their response to land use and climate change can also be expected to differ. Regional studies are needed to better understand the GDEs and their vulnerability. The role of climate variability need to be better understood (Gurdak et al., 2007) to set the potential climate change trends into a perspective. Generally, headwater ecosystems may be more vulnerable than lowland ecosystems, but headwater systems are also more adapted to natural variability. In these cases, the overall impact will depend on factors such as groundwater flow changes that bring about changes in surface water flow. Further studies are needed to show these complex couplings and interactions.

Several threats to GDEs are foreseeable in Europe, for example changes in land use, water extraction, regulation and climate change. Use of fertilisers and pesticides in agriculture is a major threat, especially if buffer zones are not established around natural ecosystems. Peatland forestry with associated land drainage is a threat to the pristine environments of northern Europe. In southern Finland, for example, almost $90 \%$ of GDEs are showing signs of change. Excavation, tunnel construction and mining have caused severe impacts by reversing flow patterns, causing wetland desiccation. These impacts can be seen in peatlands and lakes in Norway and in springs in Italy. Water extraction for irrigation has caused large declines in groundwater levels in southern Europe (Spain and Greece), which has reduced river flow locally. Low groundwater levels by the sea have been shown to have a negative impact on coastal lagoons, and this negative effect may be further accentuated by rising sea levels. Hydropower installations affect surface-groundwater exchange, with unknown consequences for riverine ecosystems.

To avoid unnecessary damage to GDEs, water managers and policy makers should be provided by updated information about the occurrence and status of GDEs. As these systems vary locally, depending on hydrogeology and climate, both local and regional studies are needed. To date, little information is available on the correct scale to understand these systems. National monitoring efforts should be conducted on the most typical ecosystems. Research is needed to better understand groundwater catchments areas of GDEs so that measures can be set correctly. Also, groundwater bodies for valuable GDEs should be delineated so that risk assessment can be carried out at the correct area (Kilroy et al., 2005). Studies to assess these systems should include multi- and interdisciplinary knowledge on e.g. hydrogeology, geochemistry and ecology to avoid wrong decisions. To understand impacts of land and water use, GDEs should be assessed, taken into account knowledge on local climate change and variability and not only on average regional recharge. As these systems are vulnerable and poorly known, decisions must be, considering uncertainty in scientific knowledge, hydrogeological setting and climate.

\section{Acknowledgements}

The work was carried out as part of the GENESIS project on groundwater systems (http://www.thegenesisproject.eu) financed by the European Commission 7FP contract 226536. We thank the referees for valuable comments that improved on the manuscript.

\section{R E F E R E N C E S}

Alfaro, C., Wallace, M., 1994. Origin and classification of springs and historical review with current applications. Environ. Geol. 24, 112-124.

Anibas, C., Buis, K., Verhoeven, R., Meire, P., Batelaan, O., 2011. A simple thermal mapping method for seasonal spatial patterns of groundwater-surface water interaction. J. Hydrol. 397, 93-104.

Arntzen, E.V., Geist, D.R., Dresel, P.E., 2006. Effects of fluctuating river flow on groundwater/surface water mixing in the hyporheic zone of a regulated, large cobble bed river. River Res. Appl. 22, 937-946.

Barquin, J., Death, R.G., 2004. Patterns of invertebrate diversity in springs and freshwater streams in northern Spain. Arch. Hydrobiol. 161, 329-349. 
Barquin, J., Scarsbrook, M., 2008. Management and conservation of coldwater springs. Aquat. Conserv, Mar. Freshwater Ecosyst. 18, 580-591.

Bonacci, O., Pipan, T., Culver, D.C., 2009. A framework for karst ecohydrology. Environ. Geol. 56, 891-900.

Borja, Á., 2005. The European water framework directive: a challenge for nearshore, coastal and continental shelf research. Continental Shelf Res. 25, 1768-1783.

Boulton, A.J., 2005. Chances and challenges in the conservation of groundwaters and their dependent ecosystems. Aquat. Conserv. 15, 319-323.

Brown, J., Wyers, A., Bach, L., Aldous, A., 2009. Groundwaterdependent biodiversity and associated threats: a statewide screening methodology and spatial assessment of Oregon. Nat. Conserv. 81.

Camargo, J.A., Alonso, Á., 2006. Ecological and toxicological effects of inorganic nitrogen pollution in aquatic ecosystems: a global assessment. Environ. Int. 32, 831-849.

Danielopol, D.L., Pospisil, P., 2001. Hidden biodiversity in the groundwater of the Danube Flood Plain National Park (Austria). Biodivers. Conserv. 10, 1711-1721.

De Luca, D.A., Ghione, R., Lasagna, M., 2005. Studio idrogeologico dei Fontanili della Pianura Piemontese. Giornale di Geologia Applicata 2, 377-382.

Devito, K.J., Hill, A.R., 1997. Sulphate dynamics in relation to groundwater-surface water interactions in headwater wetlands of the southern Canadian Shield. Hydrol. Process. 11, 485-500.

EC, 1992. Council Directive 92/43/EEC on the conservation of natural habitats and of wild fauna and flora. OJ L 206, 22.7.1992, pp. 7.

EC, 2000. Directive 2000/60/EC of the European Parliament and of the Council establishing a framework for Community action in the field of water policy. OJ L 327, 22.12.2000, p. 1.

EC, 2006. Directive 2006/118/EC of the European Parliament and of the Council on the protection of groundwater against pollution and deterioration. OJ L 372, 27.12.2006, pp. 19.

Fetter, C.W., 2001. Applied Hydrogeology, 4th edition. PrenticeHall, Inc., 598pp.

Gibert, J., Culver, D.C., Dole-Olivier, M., Malard, F., Christman, M.C., Deharveng, L., 2009. Assessing and conserving groundwater biodiversity: synthesis and perspectives. Freshwater Biol. 54, 930-941.

Gönenç, I.E., Wolflin, J.P. (Eds.), 2005. Coastal Lagoons, Ecosystem Processes and Modeling for Sustainable Use and Development. CRC Press, USA.

Gurdak, J.J., Hanson, R.T., McMahon, P.B., Bruce, Breton W., McCray, J.E., Thyne, G.D., Reedy, R.C., 2007. Climate variability controls on unsaturated water and chemical movement, high plains aquifer, USA. Vadose Zone J. 6, 533-547.

Gremaud, V., Goldscheider, N., 2010. Geometry and drainage of a retreating glacier overlaying and recharging a karst aquifer, Tsanfleuron-Sanetsch, Swiss Alps. Acta Carsolog. 39, 289-300.

Hinsby, K., de Melo, M.T.C., Dahl, M., 2008. European case studies supporting the derivation of natural background levels and groundwater threshold values for the protection of dependent ecosystems and human health. Sci. Total Environ. 401, 1-20.

Humborg, C., Pastuszak, M., Aigars, J., Siegmund, H., Moerth, C.M., Ittekkot, V., 2006. Decreased silica land-sea fluxes through damming in the Baltic Sea catchment - significance of particle trapping and hydrological alterations. Biogeochemistry 77, 265-281.

Humphreys, W.F., 2006. Aquifers: the ultimate groundwaterdependent ecosystems. Aust. J. Bot. 54, 115-132.

Ilmonen, J., 2008. Crunoecia irrorata (Curtis) (Trichoptera: Lepidostomatidae) and conservation of boreal springs: indications of clustering of red-listed species. Aquat. Conserv.: Mar. Freshwater Ecosyst. 18, 6-18.
Kilroy, G., Coxon, C., Ryan, J., O’Connor, Á., Daly, D., 2005. Groundwater and wetland management in the Shannon river basin (Ireland). Environ. Sci. Policy 8, 219-225.

Kløve, B. Andrew, A., Guillaume, B., Druzynska, E., Ertürk, A., Goldscheider, N., Henry, S., Karakaya, N., Koundouri, P., Kvœrner, J. Lundberg, A., Muotka, T., Preda, E., Pulido Velázquez, M., Schipper, P., 2011. Groundwater dependent ecosystems: Part II - ecosystem services and management under risk of climate change and land use intensification. Environ. Sci. Policy, this issue.

Kvœrner, J., Snilsberg, P., 2008. The Romeriksporten railway tunnel - drainage effects on peatlands in the lake Northern Puttjern area. Eng. Geol. 101, 75-88.

Kværner, J., Kløve, B., 2006. Tracing sources of summer streamflow in boreal headwaters using isotopic signatures and water geochemical components. J. Hydrol. 331, 186-204.

Laini, A., Bartoli, M., Castaldi, S., Viaroli, P., Capri, E., Trevisan, M., 2010. Greenhouse gas $\left(\mathrm{CO}_{2}, \mathrm{CH}_{4}\right.$ and $\left.\mathrm{N}_{2} \mathrm{O}\right)$ in lowland springs within an agricultural impacted watershed (Po River Plain, Northern Italy). Chem. Ecol. 27, 177-187.

Laio, F., Tamea, S., Ridolfi, L., D'Odorico, P., Rodriguez-Iturbe, I., 2009. Ecohydrology of groundwater-dependent ecosystems: 1. Stochastic water table dynamics. Water Resour. Res. 45, W05419, doi:10.1029/2008WR007292.

Lipka, K., Zając, E., Zarzycki, J., 2006. Course of plant succession in the post-harvest and post-fire areas of the Wielkie Błoto fen in the Niepołomice Primeveal Forest. Acta Agrophys. 7, 433-438.

Menció, A., Mas-Pla, J., 2010. Influence of groundwater exploitation on the ecological status of streams in a Mediterranean system (Salva Basin, NE Spain). Ecol. Indic. 10, 915-926.

Minelli, A., Ruffo, S., Stoch, F., Cosentino, A., La Posta, A., Morandini, C., Muscio, G., Lapini, L., Paradisi, S., Sburlino, G., Solari, M., 2002. Risorgive e fontanili, in: Acque sorgenti di pianura dell'Italia Settentronale. Ministero Dell'Ambiente, Museo Friulano di Storia Naturale. Comune di Udine 13-28.

Porst, G., Irvine, K., 2009. Distinctiveness of macroinvertebrate communities in turloughs (temporary ponds) and their response to environmental variables. Aquat. Conserv.: Mar. Freshwater Ecosyst. 19, 456-465.

Poulíčková, A., Kittner, M., Hašler, P., 2006. Vertical distribution of attached algae in shallow fishponds of different trophic status. Biologia 61, 1-9.

Ravbar, N., Goldscheider, N., 2007. Proposed methodology of vulnerability and contamination risk mapping for the protection of karst aquifers in Slovenia. Acta Carsol. 36, 397-411.

Sawyer, A.H., Cardenas, M.B., Bomar, A., Mackey, M., 2009. Impact of dam operations on hyporheic exchange in the riparian zone of a regulated river. Hydrol. Process. 23, 2129-2137.

Skeffington, M.S., Scott, N.E., 2008. Do turloughs occur in Slovenia? Acta Carsol. 37, 291-306.

Smith, H., Wood, P., Gunn, J., 2003. The influence of habitat structure and flow permanence on invertebrate communities in karst spring systems. Hydrobiologia 510, 53-66.

Šraj-Kržič, N., Germ, M., Urbanc-Berčič, O., Kuhar, U., Janauer, G.A., Gaberščik, A., 2007. The quality of the aquatic environment and macrophytes of karstic watercourses. Plant Ecol. 192, 107-118.

Stumm, W., 1992. Chemistry of the Solid-Water Interface. John Wiley and Sons, Inc., New York.

Virtanen, R., Ilmonen, J., Paasivirta, L., Muotka, T., 2009. Community concordance between bryophyte and insect assemblages in boreal springs: a broad-scale study in isolated habitats. Freshwater Biol. $54,1651-1662$. 
Ward, J.V., Tockner, K., 2001. Biodiversity: towards a unifying theme for river ecology. Freshwater Biol. 46, 807-819.

Vincenzi, V., Gargini, A., Goldscheider, N., 2009. Using tracer tests and hydrological observations to evaluate effects of tunnel drainage on groundwater and surface waters in the Northern Apennines (Italy). Hydrogeol. J. 17, 135-150.

Winter, T.C., Harvey, J.W., Franke, O.L., Alley, W.M., 1998.

Ground water and surface water; a single resource. U.S. Geological Survey Circular 1139. USGS, Denver, Colorado, pp. 79. 